\title{
The analysis of standardized precipitation index (SPI) in cotton growing Yavatmal district, Maharashtra
}

\begin{abstract}
The extremes of long term distribution of rainfall in drought hit hot semiarid agro ecoregion of Yavatmal district, Maharashtra have significant implications on rainfed cotton productivity and socioeconomic activity of farming community. In the present approach, the occurrence of week wise dry spells during crop calendar were examined with the computation of standardized precipitation Index(SPI) covering the period of 1971 to 2005 . The standard week wise rainfall analysis further showed that $27^{\text {th }}$ to $35^{\text {th }}$ week have mean of $43 \pm 35.9$ to $65 \pm 93.2 \mathrm{~mm}$ with coefficient of variation of 83.6 to 141.4 per cent. The week wise SPI values for 35 years were categorized into 6 classes such as near normal dry periods occurring $63 \%$ followed by $19.73 \%$ of normal wet periods, $5.71 \%$ of severely wet periods, $4.72 \%$ of moderately wet periods, $4.28 \%$ of extremely wet periods and $2.41 \%$ of moderately dry weeks. The occurrence of prolonged dry spells with mean of 38 to $41.36 \%$ in 36th to 44 th week during critical cotton growth stages (branching and flowering stages) often coincides with reduction in lint yield. The study demonstrated that SPI considered as valuable tool to construct historical events of dry spells and its impact on soil water content in shrink-swell soils in drought hit areas.
\end{abstract}

Keywords: rainfall variability, dry spells, semi arid, Yavatmal, cotton growing
Volume 8 Issue 6 - 2018

\author{
BP Bhaskar,' PLA Satyavati,' SK Singh, ${ }^{2}$ SG \\ Anantwar' \\ 'Division of Soil Resource Studies, ICAR-NBSS\&LUP, India \\ ${ }^{2}$ Director, ICAR-NBSS\&LUP, India
}

Correspondence: BP Bhaskar, Division of Soil Resource Studies, ICAR-NBSS\&LUP, Nagpur, Maharashtra, India Tel 09921625235,Email bhaskar_phaneendra@yahoo.co.in

Received: July 15, 2018| Published: December 20, 2018

\section{Introduction}

Drought indices such as Palmer Drought Severity Index (PDSI) and Standardized Precipitation Index (SPI) are important tools to monitor and to assess drought. The SPI has an advantage over others because of rainfall data alone and its variable time scale to describe drought conditions. ${ }^{1}$ and calculated for $3,6,12,24$, and $48^{\text {th }}$ month scales to reflect the temporal behaviour of the impact. SPI was applied to monitor the intensity and spatial extension of droughts at different time scales in South Africa. ${ }^{2}$ and in Thessaly region of Greece. ${ }^{3,4}$ carried out a study on temporal and spatial analyses of meteorological drought using SPI and hydrological drought based on theory of runs. Similarily the severity and spatial pattern of drought in Purilia district, West Bengal was studied using SPI by Moumita Palchaudhuri and Sujata Biswas. ${ }^{5}$ Many studies have been done on the impact of changing precipitation pattern in India under climate variability and its regional pattern. ${ }^{6-9}$ Dry spell in Indian summer monsoon season causes to decrease in food production. Precipitation hardly follows a typical normal distribution for the whole duration of the year, therefore standardized precipitation index (SPI) has been computed to overcome this limitation for analyzing the wet and dry spell of precipitation (Shahid, 2009). There is scanty of long term rainfall analysis of rainfed cotton belt of Yavatmal district and in workingout the wet and dry spells during crop growing season using SPI. Hence, an attempt has been made using to analyze spatial pattern of meteorological drought using SPI and analysed the seasonal changes of soil water dynamics in cotton growing shrink-swell soils of Yavatmal district, Maharashtra.

\section{Materials and methods}

\section{Study area}

Yavatmal district in the eastern vidharbha region of Maharashtra state $\left(19^{\circ} 26^{\prime}\right.$ to $20^{\circ} 42^{\prime} \mathrm{N}$ latitude and $77^{\circ} 18^{\prime}$ to $79^{\circ} 98^{\prime} \mathrm{E}$ longitude) consists of masses of Deccan trap basaltic plateaus with very steep sides and ridges or into flat-topped or pointed hills broken by broad valleys and partially surrounded by plains in north west and southern half with east-west ranges of hills. This district comes under Deccan Plateau, Hot Semi-Arid Eco-Region (6) of Western Maharashtra plateau and hot moist semi-arid eco - subregion (Figure 1) Mandal et al. ${ }^{10}$ The mean annual rainfall ranges from $1,125 \mathrm{~mm}$ of rain in eastern parts of Wani to $889 \mathrm{~mm}$ in western parts of Darwah and 1099.5 $\mathrm{mm}$ in central portion of Yavatmal showing an increasing trend as one proceeds from West to East. Yavatmal district has per capita ecologically productive land (ha) of about 0.16 ha with an ecological deficit of $0.84 \mathrm{ha}(534 \%)$. The water balance diagram of Yavatmal, Figure 1 shows that the black soils in the region are saturated with water and kept close to field capacity from June to August. It was observed in field surveys of this region and also 35 years of climatic data that soil water recovers from short dry spells with the receival of intermittent rains and restore excess water in the top soil. Delayed sowing after $15^{\text {th }}$ July resulted in drastic reduction in productivity (up to $40-50$ and needs to be irrigated at $50-70 \%$ depletion of available soil moisture. In black cotton soils 'protective irrigation' must be provided for every 20 days, if rains fail, especially during the boll development stage.

\section{Computation of SPI (Standardized precipitation index)}

The SPI is the number of standard deviations that the observed value would deviate from the long-term mean, for a normally distributed random variable. The SPI calculation for any location is based on the long-term precipitation record that is fitted to a probability distribution, which is then transformed into a normal distribution so that the mean SPI for the location and desired period is zero. The mathematical equation used to compute SPI as given under:-

$$
\Pi=\left(X_{i}^{c}-\bar{X}\right) / \sigma
$$

Where, $\Pi$ stands for SPI, $X$ for rainfall, and $\sigma$ for standard deviation of $X$ with subscript $i$ signifying the location and superscript c the time scales (monthly or seasonal). Over bar on $\mathrm{X}$ indicates 
mean climatology. Negative values of SPI indicate dry atmospheric condition or less rainfall while SPI less than -1 indicates drought. The event ends when the SPI becomes positive. Each drought event, therefore, has a duration defined by its beginning and end, and intensity for each month that the event continues. The positive sum of the SPI for all the months within a drought event can be termed the drought's "magnitude" as 2.0+extremely wet, 1.5-1.99-very wet, 1.0-1.49-moderately wet, -0.99 to +0.99 near normal, $-1.0--1.49$ moderately dry , $-1.5--1.99$ severely dry and $>-2.0$ extremely dry Drought is indicated by SPI values of -1 or below. ${ }^{11}$

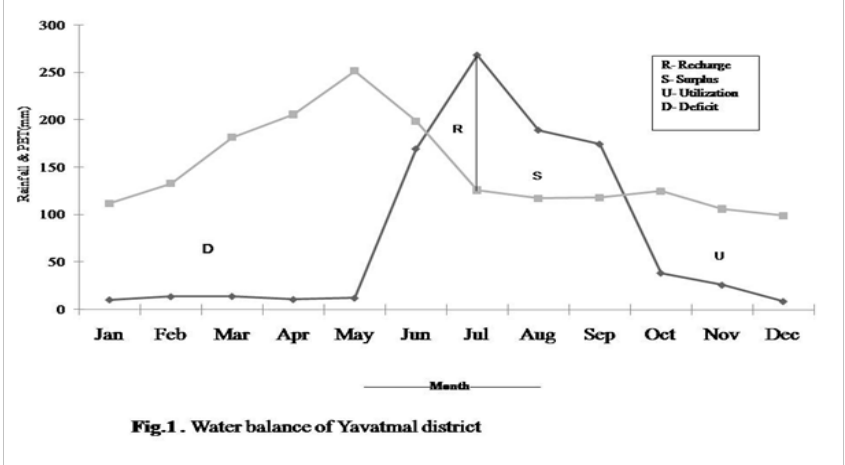

Figure I Water balance of Yavatmal district.

Table I Tehsil wise rainy days and rainfall $(\mathrm{mm})$

\begin{tabular}{|c|c|c|c|c|c|c|c|c|c|c|}
\hline \multirow[t]{2}{*}{ Tehsil } & \multicolumn{2}{|c|}{ Average } & \multirow{2}{*}{$\begin{array}{l}2004 \\
\begin{array}{l}\text { Rainy } \\
\text { days }\end{array}\end{array}$} & & Average /year (\%) & \multicolumn{4}{|c|}{ Area under crops (ha) } & \multirow[t]{2}{*}{$\begin{array}{l}\text { Total cultivated } \\
\text { area (ha) }\end{array}$} \\
\hline & $\begin{array}{l}\text { Rainy } \\
\text { days }\end{array}$ & $\begin{array}{l}\text { Rainfall } \\
(\mathrm{mm})\end{array}$ & & Rainf & III (mm) & Cotton & Jowar & $\begin{array}{l}\text { Red } \\
\text { gram }\end{array}$ & Gram & \\
\hline I.Ner & 47 & 587 & 45 & 329 & 56 & 29870 & 8836 & 3539 & 80 & 50918 \\
\hline 2.Arni & 47 & 594 & 34 & 282 & 48 & 29177 & 12215 & 4052 & 250 & 58337 \\
\hline 3.Kelapur & 56 & 1052 & 46 & 830 & 79 & 26947 & 13954 & 4891 & 58 & 51483 \\
\hline 4.Babulgaon & 55 & 909 & 43 & 462 & 51 & 26139 & 8960 & 5229 & 74 & 45211 \\
\hline 5.Ralegaon & 57 & 1742 & 47 & 524 & 30 & 31956 & 12009 & 5884 & 822 & 58505 \\
\hline 6.Maregaon & 55 & 882 & 40 & 327 & 37 & 23970 & 8748 & 4942 & 147 & 42417 \\
\hline 7.Jhari Jamni & 50 & 653 & 48 & 324 & 50 & 24449 & 6227 & 1685 & 70 & 40812 \\
\hline 8. Kalamb & 58 & 1275 & 43 & 388 & 30 & 28811 & 11726 & 4647 & 158 & 50418 \\
\hline 9.Darhwa & 51 & 962 & 43 & 424 & 44 & 33925 & 19121 & 2865 & 156 & 63930 \\
\hline I0.Mahagaon & 58 & 1309 & 46 & 451 & 34 & 31063 & 14226 & 2738 & 46 & 59158 \\
\hline I I.Ghatanji & 53 & 1149 & 40 & 438 & 38 & 37968 & 13888 & 1167 & 73 & 56630 \\
\hline 12. Yavatmal & 62 & 1180 & 58 & 662 & 56 & 30214 & 12133 & 3432 & 230 & 57639 \\
\hline 13..Digras & 50 & 964 & 43 & 462 & 48 & 18923 & 8977 & 2685 & 167 & 37955 \\
\hline |4.Pusad & 53 & 1066 & 39 & 477 & 45 & 28839 & 21280 & 3445 & 83 & 72326 \\
\hline I5.Umarkhed & 55 & 669 & 39 & 357 & 53 & 24602 & 11324 & 2330 & 3123 & 78825 \\
\hline 16.Wani & 62 & 1400 & 50 & 592 & 42 & 34428 & 9310 & 4725 & 565 & 59308 \\
\hline Total area (ha) & & & & & & $46 \mid 281$ & 192934 & 58250 & 6102 & 883872 \\
\hline Total area(\%) & & & & & & 52.2 & 21.8 & 6.6 & 0.7 & \\
\hline
\end{tabular}

$\mathrm{Ha}$, hectare; mm, millimetre; \%, per cent

Citation: Bhaskar BP, Satyavati PLA, Singh SK, et al. The analysis of standardized precipitation index (SPI) in cotton growing Yavatmal district, Maharashtra. Adv Plants Agric Res. 20 I8;8(6):505-5 I0. DOI: I0.15406/apar.2018.08.00376

\section{Results and discussion}

\section{Rainfall analysis} 2005 was used to calculate monthly mean and standard deviations of rainfall. The data shows that August and July receives peak rainfall $(250$ to $320 \mathrm{~mm})$ with maximum deviation from mean. The rainfall begins in June and retreats in second week of October. The mean rainfall during September and October is 50 to $200 \mathrm{~mm}$ with maximum variations from the mean. Tehsil wise average rainy days and average rainfall $(\mathrm{mm})$ is recored as mean rainfall of $1180 \mathrm{~mm}$ with 62 average rainy days in Yavatmal (Northern side) to minimum of 587 $\mathrm{mm}$ of rainfall in Ner with 47 rainy days (Table 1). The major crops are cotton $(52 \%$ of total area ) followed by Jower $(22 \%)$ and Redgram $(6.6 \%)$. The monthly mean rainfall $(\mathrm{mm})$ data shows that June, July and August are peak rainy months and receeds after September onwards. Standard week wise rainfall and rainy days shows that $27^{\text {th }}$ with $\mathrm{CV}$ of 35.98 to $53.9 \%$. The mean rainy days for these weeks are four for $27^{\text {th }}$ week to 3.8 for $34^{\text {th }}$ week with $\mathrm{CV}$ of 50 to $52 \%$. The gradual decrease in mean amount of rainfall from $36^{\text {th }}$ to $45^{\text {th }}$ week with CV of 137.5 to $280.47 \%$. Similar trends are noticed for rainy days with mean less than 1 from 43 to $45^{\text {th }}$ week and CV of 180 to $237 \%$ (Table 2).
The thirty five years of rainfall data during the period of 1971 to to $34^{\text {th }}$ week have mean amount of rainfall of $43.03 \mathrm{~mm}$ to $54.25 \mathrm{~mm}$ 
Table 2 Standard week-wise descriptive statistics for amount of rainfall and rainy days

\begin{tabular}{|c|c|c|c|c|c|c|c|c|}
\hline \multirow[t]{2}{*}{$\begin{array}{l}\text { Standard } \\
\text { week }\end{array}$} & \multicolumn{4}{|c|}{ Amount of rainfall } & \multicolumn{4}{|c|}{ Rainy days } \\
\hline & $\begin{array}{l}\text { Sum } \\
(\mathrm{mm})\end{array}$ & $\begin{array}{l}\text { Mean } \\
(\mathrm{mm})\end{array}$ & $\begin{array}{l}\text { Standard } \\
\text { deviation }\end{array}$ & $\begin{array}{l}\text { Coefficient of } \\
\text { variation (\%) }\end{array}$ & $\begin{array}{l}\text { Sum } \\
(\mathrm{mm})\end{array}$ & $\begin{array}{l}\text { Mean } \\
(\mathrm{mm})\end{array}$ & $\begin{array}{l}\text { Standard } \\
\text { deviation }\end{array}$ & $\begin{array}{l}\text { Coefficient of } \\
\text { variation (\%) }\end{array}$ \\
\hline 20 & 227.4 & 5.92 & 15.07 & 254.28 & 20 & 0.57 & 0.81 & 142.58 \\
\hline 21 & 195.8 & 4.99 & 12.28 & 245.96 & 19 & 0.54 & 0.7 & 129.05 \\
\hline 22 & 302 & 8 & 18.07 & 225.91 & 32 & 0.91 & 1.22 & 133.61 \\
\hline 23 & 714.4 & 19.75 & 33.81 & 171.18 & 68 & 1.94 & 1.79 & 92.53 \\
\hline 24 & 1846 & 52.04 & 76.53 & 147.06 & 107 & 3.05 & 1.75 & 57.17 \\
\hline 25 & 2189 & 61.84 & 52.41 & 84.76 & 133 & 3.8 & 1.89 & 49.76 \\
\hline 26 & 2421 & 68.44 & 82.72 & 120.9 & 140 & 4 & 2.03 & 50.72 \\
\hline 27 & 1533 & 43.03 & 35.98 & 83.6 & 136 & 3.88 & 1.95 & 50.23 \\
\hline 28 & 2517 & 71.12 & 66.32 & 93.26 & 161 & 4.6 & 1.83 & 39.87 \\
\hline 29 & 2582 & 72.93 & 68.85 & 94.39 & 159 & 4.54 & 1.8 & 39.71 \\
\hline 30 & 1971 & 55.47 & 57.69 & 104 & 144 & 4.11 & 1.99 & 48.52 \\
\hline 31 & 2769 & 78.24 & 75.76 & 96.83 & 154 & 4.4 & 1.95 & 44.84 \\
\hline 32 & 2584 & 72.92 & 63.78 & 87.46 & 163 & 4.65 & 1.71 & 41.96 \\
\hline 33 & $|89|$ & 53.09 & 44.4 & 83.64 & 146 & 4.17 & 1.71 & 40.9 \\
\hline 34 & 1933 & 54.25 & 53.9 & 99.35 & 134 & 3.82 & 1.99 & 52.04 \\
\hline 35 & 2341 & 65.89 & 93.15 & $|4| .4$ & 123 & 3.51 & 2.09 & 59.51 \\
\hline 36 & 1388 & 38.62 & 53.09 & 137.5 & 109 & 3.11 & 2.08 & 66.89 \\
\hline 37 & 821.6 & 22.42 & 26.4 & 117.7 & 87 & 2.48 & 2.12 & 85.27 \\
\hline 38 & 1185 & 32.77 & 57.52 & 175.5 & 72 & 2.06 & 1.99 & 97.18 \\
\hline 39 & 980.5 & 26.9 & 33.34 & 123.9 & 88 & 2.51 & 2.09 & 83.19 \\
\hline 40 & 966.1 & 26.46 & 37.48 & 141.6 & 63 & 1.8 & 1.84 & 102.43 \\
\hline 41 & 545 & 14.4 & 23.24 & 161.4 & 37 & 1.06 & 1.21 & 114.58 \\
\hline 42 & 473.9 & 12.34 & 24.42 & 197.89 & 35 & I & 1.37 & 137.19 \\
\hline 43 & 313.2 & 7.72 & $|7.2|$ & 222.95 & 27 & 0.77 & 1.39 & 180.84 \\
\hline 44 & 91.6 & 1.36 & 2.9 & 213.33 & 14 & 0.4 & 0.69 & 173.62 \\
\hline 45 & 213.7 & 4.82 & $|3.5|$ & 280.47 & 9 & 0.26 & 0.61 & 237.54 \\
\hline
\end{tabular}

\section{Precipitation index}

The semiarid Yavatmal district, precipitation is quite variable and shows fluctuations in its distribution and quantity that have significant implications on agricultural productivity, food security, land use as well as ecological impacts. The week-wise SPI values were calculated during crop calendar for 35 years (1971 to 2005) and categorized into 6 classes (Table 3 ). The near normal dry periods are $63 \%$ followed by $19.73 \%$ of normal wet periods, $5.71 \%$ of severely wet periods, $4.72 \%$ of moderately wet periods, $4.28 \%$ of extremely wet periods and 2.41
$\%$ of moderately dry weeks. The occurrence of the normal dry weeks exceeding more than 18 out of 26 weeks in 11 years and nine years with 8 wet weeks during $25^{\text {th }}$ to $35^{\text {th }}$ standard week of cotton growing period in the region with severe water stress for $40^{\text {th }}$ to $45^{\text {th }}$ standard week. The decadal rainfall data shows that there is gradual increase of number of occurence of dry weeks from 1971 to 2005 . It is observed from the data that there is increase of dry weeks more than 15 in 5 years from 1970 to 1980 but increased to 7 years from 1981 to 1990 and 9 years from 1991 to 2000 .The dry weeks from 2001 to 2005 is almost normal drought like situations in the district. 
Table 3 Year wise classification and characterization of standardized precipitation index in defining wet and dry weeks

\begin{tabular}{|c|c|c|c|c|c|c|}
\hline \multirow{2}{*}{ Year } & \multicolumn{6}{|c|}{ SPI Classification (Weeks) } \\
\hline & Normal dry & Moderately dry & Normal wet & Moderately wet & Severely wet & Extremely wet \\
\hline 1971 & 18 & I & 4 & 1 & 1 & 1 \\
\hline 1972 & 19 & 1 & 5 & 0 & 1 & 1 \\
\hline 1973 & 14 & I & 8 & I & 2 & I \\
\hline 1974 & 14 & 3 & 7 & 0 & 2 & 3 \\
\hline 1975 & 14 & 0 & 7 & 3 & 2 & 0 \\
\hline 1976 & 14 & 0 & 7 & 3 & 2 & 0 \\
\hline 1977 & 16 & I & 7 & 0 & 1 & 1 \\
\hline 1978 & 19 & 0 & 5 & 0 & 0 & 0 \\
\hline 1979 & 15 & 1 & 6 & 2 & 2 & 1 \\
\hline 1980 & 18 & 0 & 3 & 2 & 3 & 0 \\
\hline 1981 & 15 & 0 & 7 & 2 & 2 & 0 \\
\hline 1982 & 16 & 1 & 7 & I & 0 & I \\
\hline 1983 & 11 & I & 7 & 0 & 1 & 6 \\
\hline 1984 & 17 & 2 & 4 & I & 0 & 2 \\
\hline 1985 & 19 & 1 & 3 & I & 1 & I \\
\hline 1986 & 15 & 0 & 7 & 3 & 0 & I \\
\hline 1987 & 20 & 0 & 3 & 3 & 0 & I \\
\hline 1988 & 12 & I & 8 & I & 3 & I \\
\hline 1989 & 17 & 0 & 5 & 2 & 0 & 2 \\
\hline 1990 & 11 & 4 & 7 & 2 & 2 & 0 \\
\hline 1991 & 21 & 0 & 3 & I & I & 0 \\
\hline 1992 & 18 & 1 & 4 & 1 & 1 & I \\
\hline 1993 & 17 & 0 & 5 & 3 & 0 & I \\
\hline 1994 & 17 & 0 & 6 & 2 & 1 & 0 \\
\hline 1995 & 16 & 1 & 2 & 2 & 2 & 3 \\
\hline 1996 & 18 & 0 & 5 & 0 & 2 & I \\
\hline 1997 & 16 & 2 & 5 & 0 & 1 & 2 \\
\hline 1998 & 20 & 0 & 5 & 0 & 1 & 0 \\
\hline 1999 & 15 & 2 & 3 & I & 2 & 3 \\
\hline 2000 & 18 & 0 & 2 & I & 4 & I \\
\hline 2001 & 15 & 1 & 6 & 0 & 3 & I \\
\hline 2002 & 18 & 0 & 2 & 0 & 4 & 2 \\
\hline 2003 & 15 & 0 & 6 & 1 & 3 & I \\
\hline 2004 & 19 & 0 & 6 & I & 0 & 0 \\
\hline 2005 & 18 & 1 & 3 & 2 & 2 & 0 \\
\hline number of weeks & 575 & 22 & 180 & 43 & 52 & 39 \\
\hline Per cent of total & 63.2 & $2.4 I$ & 19.75 & 4.72 & 5.71 & 4.28 \\
\hline
\end{tabular}

SPI, standardized precipitation index 


\section{Seasonal factors influencing soil water dynamics}

The climate in Yavatmal district is hot Semi-arid eco-region with four seasons such as: hot season (March and extends up to the first week of June), south west monsoon season (June $2^{\text {nd }}$ week to till the 1 st week of September), post monsoon season ( $2^{\text {nd }}$ week of September to $1^{\text {st }}$ week of December) and cold season $\left(2^{\text {nd }}\right.$ week of December to till February) with the mean daily minimum temperature at about $13{ }^{\circ} \mathrm{C}$. The cold waves over northern India sometimes affect the district and the minimum temperature may drop to about $5^{\circ} \mathrm{C}$. It is reported that the monsoon sowing, $24^{\text {th }}$ to $25^{\text {th }}$ meteorological week (15 June to 5 July) is optimum for cotton sowing in the region with minimum of 30 to $40 \%$ of rainfall. The shallow, medium deep and deep shrink-swell soils account for 35,50 and $15 \%$ of total area with an average water content (AWC) ranging from $100-500 \mathrm{~mm} / \mathrm{m}$, a slope of $0.5-3 \%$, well to moderately drained, with a soil depth ranging from 0.6 to $0.9 \mathrm{~m}$ and a $\mathrm{pH}$ of between 7.0-8.2. The water retention curve of shrink-swell soils were similar with respect to depth of layers showing decreasing soil water content with the increase of water suction applied. The water content decreased at $800 \mathrm{kPa}$ as the curves of cambic and slickensided horizons intersect with each other with soil water values of 25 to $50 \%$ from 1 to $800 \mathrm{kPa}$. At field capacity the water suction for top A horizon is $20 \mathrm{kPa}$ but of $30 \mathrm{kPa}$ for cambic and slicken sided zones (Figure 2). Depending upon the irregularities in soil water movement under hot semiarid climate, the shrink-swell soils experiences the period of wet stage and alternate wet - dry stages during cotton growing season. These soils have $12.7 \%$ of mean plant available water content with standard deviation of $2.95 \%$ and negative relation with $\mathrm{CaCO}_{3}$ content $\left(\mathrm{r}=-0.41^{*}\right.$, significant at $1 \%$ level). The clay and fine clay has a significant positive relation with water held at-33 $\mathrm{kPa}$ and -1500 $\mathrm{kPa}{ }^{12}$ The plant available water can be approximated with multiple regression equation with $\mathrm{R}^{2}$ value of 0.29 , and $\mathrm{F}$ value of 2.25 .

Plant available water $(\%)=-6.39+0.156$ (sand) +0.283 (silt $\%)+0.189($ clay \%) -0.433 (organic carbon $\mathrm{g} / \mathrm{kg})-0.022$ (calcium carbonate, $\mathrm{g} / \mathrm{kg}$ )

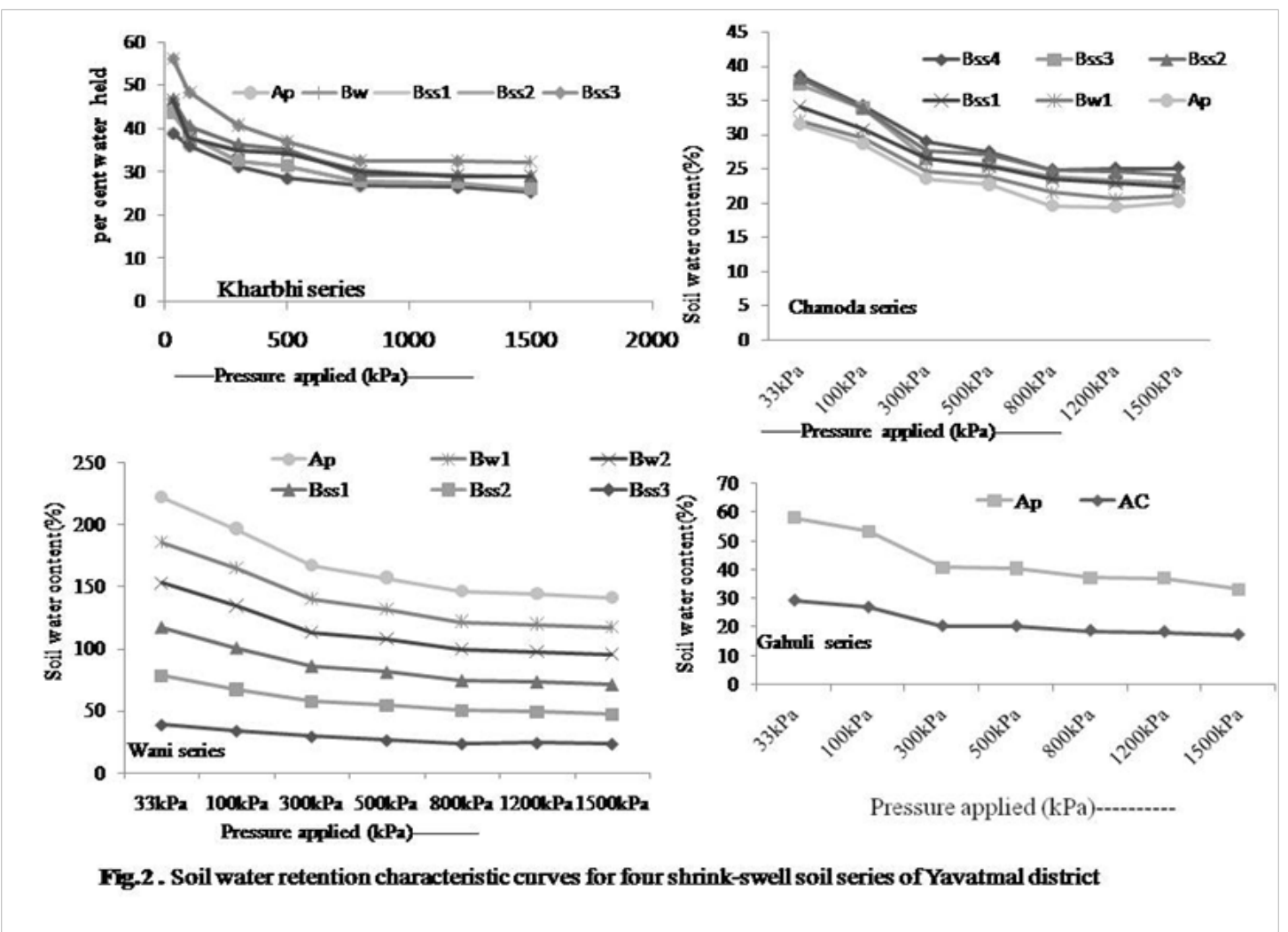

Figure 2 Soil water retention characteristic curves for four shrink- swell soil series of Yavatmal district.

The dry stage is often with at least 15 days of dry spells after September $15^{\text {th }}$ and have rainfall of less than $20 \%$ of total precipitation which often coincide with flowering and boll development stages of cotton. During this period, the top A horizon has low soil water content and reaches to wilting point. The stored water in subsoils is used by crop in times delay in rains and often experiences drought like situations with prolonged dry spells. The water stress occurs when cotton attains early bloom stage and is highly sensitive to water stress. The water content of shrink-swell soils in the region varies from the zone of $0-40 \mathrm{~cm}$ at the rate of 14 to $32 \%$ to 24 to $32 \%$ from the zone of $40-110 \mathrm{~cm}$ and 28 to $32 \%$ from the zone of, $110-260 \mathrm{~cm} .{ }^{13}$ The change in soil water at $0-20 \mathrm{~cm}$ in the cotton growing season (from June to February) is main supplying water source to support seedling emergence to primordial branching stage and sensitive to water stress that ultimately influence lint yield. Late sowing because of the late arrival of the monsoon leads to a significant yield loss due to terminal moisture stress as well as low temperature effect in the months of December and January. ${ }^{14}$

\section{Conclusion}

In the present approach, the occurrence of week wise dry spells during cotton crop calendar were examined with the computation of standardized precipitation Index(SPI) for the period of 1971 to 2005. The weekwise rainfall analysis revealed that $63 \%$ of crop season experiences near normal dry periods with prolonged dry spells in $36^{\text {th }}$ to $44^{\text {th }}$ week during critical growth stages (branching and flowering 
stages). The study demonstrated that SPI considered as valuable tool to construct historical events of dry spells in drought hit areas and had strong influence on change in soil water at $0-20 \mathrm{~cm}$. It was observed that there is increase of dry weeks more than 15 in 5 years from 1970 to 1980 but increased to 7 years from 1981 to 1990,9 years from 1991 to 2000 and normal drought like situation from 2001 to 2005 .

\section{Acknowledgments}

Authors wish to express their sincere thanks to The Head and his staff Regional Agricultural Research Station, Yavatmal, PDKV, Akola for providing agrometeorological data to carry out analysis of rainfall in the region.

\section{Conflicts of interest}

I hereby declare that there is no financial interest and any other conflict of interests exist in this project work done by me at NBSS\&LUP, Nagpur under the Institute approve project.

\section{References}

1. McKee TB, Doesken NJ, Kleist J. The relationship of drought frequency and duration of time scales. Eighth Conference on Applied Climatology, American Meteorological Society. 1993;179-186.

2. Rouault M, Richard Y. Intensity and Spatial Extension of Drought in South Africa at Different time Scale. Water SA. 2003;29(4).

3. Loukas A, Vasiliades L. Probabilistic analysis of Drought spatiotemporal characteristics in Thessaly region, Greece. Natural Hazards and Earth System Sciences. 2004; 4(5/6):719-731.

4. Edossa DC, Babel MS Gupta AD. Drought Analysis in the Awash River Basin, Ethiopia. Water Resource Management. 2010;24(7):1441-1460.

5. Moumita P, Sujata B. Analysis of Meteorological Drought Using
Standardized Precipitation Index - A Case Study of Puruliya District, West Bengal, India. International Journal of Environmental, Ecological, Geological and Mining Engineering. 2013;7(3):119-126.

6. Ashok K, Saji NH. On the impact of ENSO and Indian Ocean dipole events on subregional Indian summer monsoon rainfall. Nat Hazards. 2009;42(2):273-285.

7. Ghosh S, Luniya V, Gupta A. Trend analysis of Indian summer monsoon rainfall at different spatial scales. Atmos Sci Lett. 2009;10(4):285-290.

8. Goswami BN, Venugopal V, Sengupta D, et al. Increasing trend of extreme rain events over India in a warming environment. Science. 2006; 314(5804):1442-1445.

9. Pal I, Al-Tabbaa A. Regional changes in extreme monsoon rainfall deficit and excess in India. Dynam Atmos Ocean. 2009;49:206-214.

10. Mandal C, Mandal DK, Srinivas CV, et al. Soil climatic database for crop planningin India. National Bureau of Soil Survey \& Land Use Planning (ICAR). 1999; 994p.

11. Edwards DC, McKee TB. Characteristics of 20th Century drought in the United States at multiple time scales. Climatology Report Number 972, Department of Atmospheric Science, Colorado State University, Fort Collins. 1997;429-449.

12. Bhaskar BP, Dipak Sarkar, Bobade SV, et al. Land resource evaluation for optimal land use plans in cotton growing yavatmal district, Maharashtra. The Ecoscan. 2011;1:251-259.

13. Meng K, Zhang X, Sui Y, et al. Analysis of water characteristics of black soils over long term experimental researches in North East China. Bulg J Plant Physiol. 2004;30(3-4):111-120.

14. Hebbar KB, Venugopalan MV, Rao MRK, et al. Effect of sowing dates and fertilizer levels on phenology, growth and yield of cotton. Indian $J$ Plant Physiol. 2003;7(4):380-383. 